\title{
The Way Forward
}

\author{
Ulrich A. K. Betz
}

In this chapter, I would like to share some personal thoughts and ideas that developed in my mind while conducting the activities around the science and technology workstream at the occasion of Merck's 350th anniversary.

In the almost two years spent in preparation and operational execution of the various activities around science, technology and innovation, it was impressive not only to see the tremendous impact science and technology had over the millennia and what breakthroughs are ahead (Betz 2018, Is the force awakening? Technology Forecasting and Social Change 128, 296) but also how working on these fascinating topics can energize people to join forces and work on further advancement in highly motivated teams, across cultural, religious and national boundaries.

Advancements in science and technology however go hand in hand with ethical questions. We have seen from human history that new technologies often not only come with inherent risks and undesirable side effects but in general can be used for good and evil alike. Science and tech-

The original version of this chapter was inadvertently published as non-open access. It has now been changed to open access with the copyright holder name "The Author(s)". The correction to this chapter is available at [https://doi.org/10.1007/978-3-030-16061-6_18]

\section{U. A. K. Betz $(\square)$}

Vice President Innovation Merck,

Darmstadt, Germany

e-mail: ulrich.betz@merckgroup.com nology itself are ethically neutral, and we need to ensure that they are applied for the greater good.

Most important of all, science and technology remain silent on the essential question of live: For what purpose do we live and what should we do?

This question has been the domain of religion and philosophy and although there are wide differences between different religions and philosophies in regard to detailed rules and regulations, rites and believes, it is remarkable that there seems to be a set of fundamental principles that form the core, many of which are essentially identical on what constitutes ethical behavior, on how a good live should look like and what should guide our activities.

Just compare, for example, two moral codices that emerged independently in human history at two different locations, the Ten Commandments as described in the Bible (2. Mose, 20) and the Five Precepts of Buddhism (Sanskrit: pañcaśîla) (Table 17.1).

In the following, I delineate fundamental principles that could guide how we apply the benefits of science and technology:

Fundamental principle 1: Truth

Discovering and communicating the truth on what is, how the universe is working, is at the core of the scientific method. Science is the search for truth and the fundamental principle of truth is universally accepted in science (e.g., the 
Table 17.1 Agreement between the Ten Commandments and the Five Precepts

\begin{tabular}{l|l}
\hline 6. Commandment: Thou shalt not kill & 1. Precept: Refrain from taking lives \\
\hline $\begin{array}{l}\text { 7. Commandment: Thou shalt not commit adultery } \\
\text { 8. Commandment: Thou shalt not steal }\end{array}$ & $\begin{array}{l}\text { 3. Precept: Refrain from sexual } \\
\text { misconduct }\end{array}$ \\
\hline $\begin{array}{l}\text { 9. Commandment: Thou shalt not bear false witness against thy } \\
\text { neighbor }\end{array}$ & 2. Precept: Refrain from stealing \\
\hline
\end{tabular}

motto of Harvard University is VERITAS). In his Metaphysics, Aristotle stated: "To say of what is that it is not, or of what is not that it is, is false, while to say of what is that it is, and of what is not that it is not, is true." The original meaning and essence of truth in ancient Greece ("aletheia") was the revealing of what was previously hidden into the open. Likewise, the 9th commandment and the 4th precept both underline the importance of communicating the truth.

\section{Fundamental principle 2: Love}

Love (agape, charity) as a fundamental principle affecting the relationship between ourselves and our fellow human beings is a key topic of all moral and ethical discourse. Christian/Jewish commandments 6-9 and Buddhist precepts 1-4 can basically be summarized as "do no harm to others." In the New Testament, all ethics is summarized by Jesus in one sentence (the great commandment as in Matthew 22:35-40 and Mark 12:28-34): "Love God with all your mind and with all your strength, love your neighbor as you love yourself. There is no commandment more important than these." Another statement in philosophy summarizing this principle is the "categorical imperative" from Immanuel Kant: "Act only according to that maxim whereby you can, at the same time, will that it should become a universal law." or the famous "Golden Rule." The Golden Rule is the principle of treating others as one's self would wish to be treated. It is a maxim that is found in many religions and cultures and appears prominently in Christianity, Judaism, Buddhism, Hinduism, Konfuzianism and Taoism. The concept of the Golden Rule is also codified in the Code of Hammurabi stele and tablets (1790 BC).

\section{Fundamental principle 3: Courage}

The virtue of courage (fortitude, valor or bravery) is an integral part of ancient western and eastern traditions. It is mentioned by ancient Greek philosophers Socrates, Plato and Aristoteles, the Roman philosopher and statesman Cicero lists it as one of the four virtues: courage, wisdom, justice and temperance. In Catholicism, courage is one of the seven gifts of the Holy Spirit (fortitude/courage, wisdom, understanding, counsel, knowledge, piety and fear of the Lord). In Hindu tradition, courage (shauriya) appears as the first of then characteristics (courage, patience, forgiveness, tolerance, honesty, physical restraint, cleanliness, perceptiveness, knowledge, truthfulness and control of anger). Courage is the basis for all action, linked with the strive to accomplish and willing to bear risk and sacrifice. It is the essence of entrepreneurship that is required to bring the benefits of science and technology to fruition to have impact in the world.

\section{Fundamental principle 4: Liberty}

Philosophers from earliest times have considered the topic of liberty. Roman Emperor Marcus Aurelius (121-180 AD) wrote: "a polity in which there is the same law for all, a polity administered with regard to equal rights and equal freedom of speech, and the idea of a kingly government which respects most of all the freedom of the governed." Aristotle put it: "This, then, is one note of liberty which all democrats 
affirm to be the principle of their state. Another is that a man should live as he likes. This, they say, is the privilege of a freeman, since, on the other hand, not to live as a man likes is the mark of a slave. This is the second characteristic of democracy, whence has arisen the claim of men to be ruled by none, if possible, or, if this is impossible, to rule and be ruled in turns; and so it contributes to the freedom based upon equality." The first draft of liberty in continental Europe after the Roman Empire is the Twelve Articles as part of the peasants' demands of the Swabian League during the German Peasants' War of 1525 stating that "Christ redeemed all of us with his precious bloodshed, the shepherd as well as the highest, no one excluded. Therefore, it is devised by the scripture, that we are and that we want to be free." Finally and most famous, according to the 1776 United States Declaration of Independence, all men have a natural right to "life, liberty, and the pursuit of happiness." This then consequently would also involve the freedom to neglect the fundamental principles described here (Fig. 17.1).

Applying these fundamental principles can lead to a new way of working together, a new type of organization, that combines the strong cultural traditions of science (truth), religion (love) and entrepreneurship (courage) while at the same time being based on individual freedom (liberty). The four general principles of truth, love, courage and liberty can help us to find the right way forward and to apply further progress in science and technology for the benefit of all humanity. Keeping this in mind, we can combine constant change and innovation with neverchanging eternal truths to a force of good that can change the face of the world.

And finally, there might be a fifth fundamental principle: spirituality. A notion that there is more than energy and matter, that there is spirit, that there is the "I am that I am," the alpha and the omega of all things, the end and the beginning.

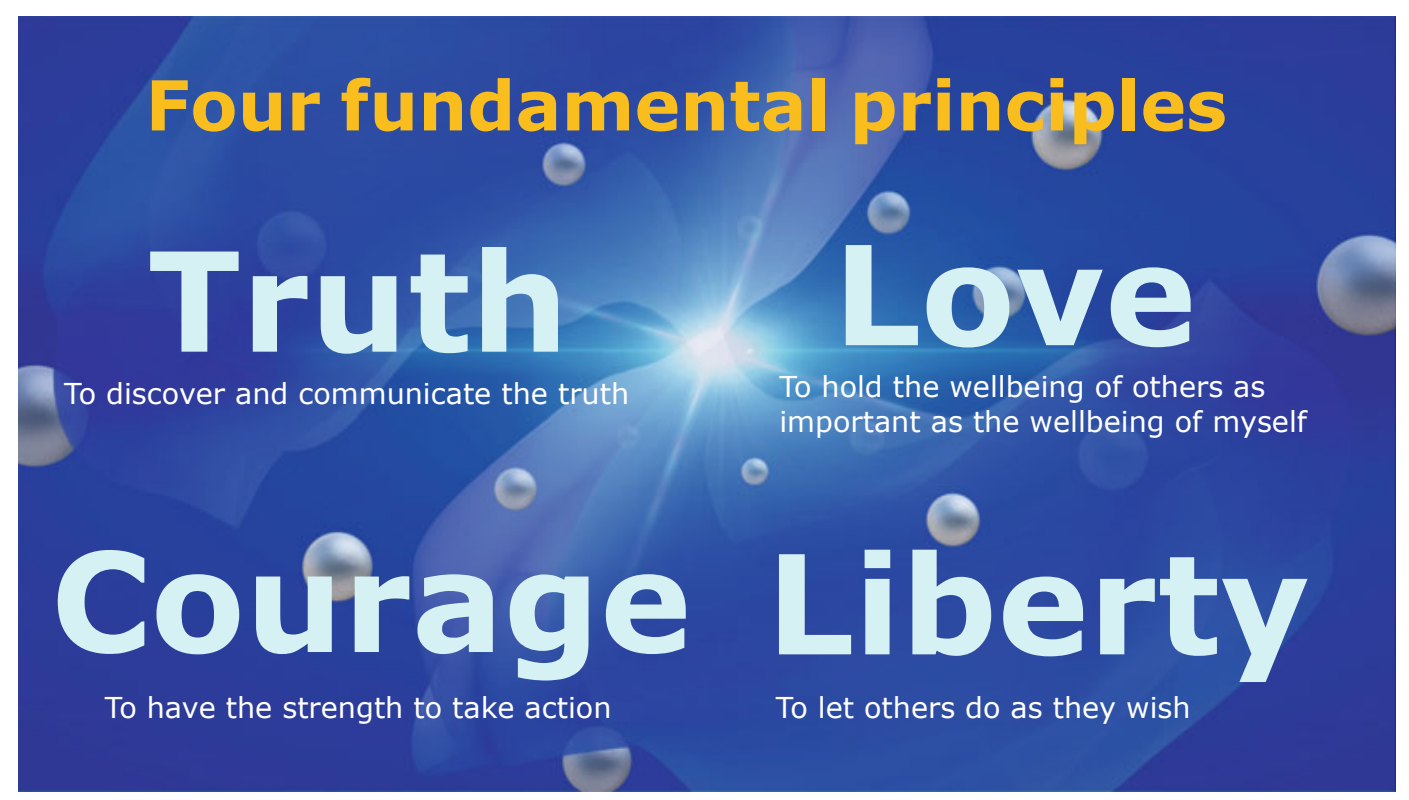

Fig. 17.1 Four fundamental principles 
Open Access This chapter is licensed under the terms of the Creative Commons Attribution-NonCommercial 4.0 International License (http://creativecommons.org/ licenses/by-nc/4.0/), which permits any noncommercial use, sharing, adaptation, distribution and reproduction in any medium or format, as long as you give appropriate credit to the original author(s) and the source, provide a link to the Creative Commons license and indicate if changes were made.
The images or other third party material in this chapter are included in the chapter's Creative Commons license, unless indicated otherwise in a credit line to the material. If material is not included in the chapter's Creative Commons license and your intended use is not permitted by statutory regulation or exceeds the permitted use, you will need to obtain permission directly from the copyright holder.

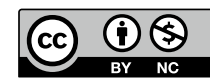

